This item was submitted to Loughborough's Research Repository by the author.

Items in Figshare are protected by copyright, with all rights reserved, unless otherwise indicated.

\title{
Victimisation and re-victimisation risk, housing type and area: a study of interactions
}

PLEASE CITE THE PUBLISHED VERSION

PUBLISHER

(C) Perpituity Press

LICENCE

CC BY-NC-ND 4.0

REPOSITORY RECORD

Bowers, Kate J., Shane D. Johnson, and Ken Pease. 2019. "Victimisation and Re-victimisation Risk, Housing Type and Area: A Study of Interactions". figshare. https://hdl.handle.net/2134/849. 


\title{
Victimisation and Re-victimisation Risk, Housing Type and Area: A Study of Interactions
}

\begin{abstract}
Kate J. Bowers, Shane D. Johnson and Ken Pease ${ }^{1}$
It is often assumed that less ostensibly affluent homes (eg terraced housing) are more at risk than other types of housing (such as detached houses) of being burgled. The research reported here shows these patterns to be strongly influenced by the area in which houses are located. The results demonstrate that detached houses in deprived areas are particularly vulnerable to both victimisation and repeat victimisation. In such areas, detached houses are at over three times the risk of being burgled than terraced housing. Furthermore, the results demonstrate that the influences of area and housing type interact. For instance, detached houses located in deprived areas are at over seven times the risk of detached houses in affluent areas. Consequently, crime prevention agencies are cautioned against simply using area-level indices of deprivation when targeting resources, or assuming that housing most often associated with individual-level deprivation should be the first in line for assistance.
\end{abstract}

Key Words: Victimisation; repeat victimisation; housing type; deprivation; resource targeting; ecological fallacy

\section{Introduction}

Research consistently demonstrates an association between area deprivation and both property offences (Block, 1979) and violent crime (Curry and Spurgel, 1988). Offender activity and crime incident rates have been found to be higher in various locations in Britain which are more deprived in social and economic terms, including Cardiff (Herbert, 1977), Merseyside (Hirschfield et al, 1995) and Sheffield (Baldwin and Bottoms, 1976). It has also been found that levels of repeat victimisation, where the same household is victimised on multiple occasions, is also higher in such areas (Johnson et al, 1997). It is important to note that in most criminological theory the association between risk and deprivation is not taken to be directly causal. Deprivation is more properly thought of as a feature of areas which are high in social disorganisation (Bursik, 1988) or low in collective efficacy (Sampson and Raudenbusch, 1999).

However, there is a tendency for practitioners to think in terms of a more or less direct causal link between deprivation and crime at the individual level. For example, Calderdale Council argues that:

Several socio-economic factors affect the likelihood of being a victim as well as committing an offence. In Calderdale the postcodes with the highest levels of crime tend to rank highest in terms of deprivation. ${ }^{2}$

The problem with this line of reasoning is the implicit assumption that relationships which are apparent at the aggregate level are equally valid at the individual level. Making such assumptions is to commit the ecological fallacy (Durkheim, 1897). 
Thus, one question that is important to answer is whether it is fair to assume that it is the most deprived households within a deprived area that have the highest risk of, say, property crime associated with them. Or is it the case that more affluent households are particular targets within such areas? Tseloni et al review the relevant studies as follows:

[S]tudies agree that both types of explanatory variable (individual and community) significantly affect household victimization risk. Indeed, the factors at these two different levels can have counteracting influences. 'To caricature, richer people in poorer areas suffer property crime particularly heavily' (Trickett et al, 1995:291). This finding about the different roles of household and area affluence recurs in a number of other papers and relates to studies of household crime rates (Osborn and Tseloni, 1998) as well as to crime risks (Osborn et al, 1996; Osborn and Tseloni 1998). (2002:112)

\section{The influence of housing type}

One important factor that influences the risk of victimisation is residential housing type (eg Maguire, 1982; Winchester and Jackson, 1982; Budd, 1999; Kershaw et al, 2000). There are a number of ways in which such a relationship might arise.

- The impressiveness of a home's external aspect may promise treasures for the burglar within.

- $\quad$ A home that appears to be well kept may suggest owners who value their home and equip it correspondingly well, have money to spend and hence own valuable goods.

- In areas with homogeneous housing, housing type is likely to play little or no role in influencing offenders' targeting decisions. However, in areas where housing is more heterogeneous or where particular types of housing tend to stand out it may play a fairly considerable role.

- $\quad$ Properties vary in their number of entry points. For example, terraced properties generally have two or three ground-floor windows and two doors, while detached housing may have twice as many windows. In this sense, detached housing may be argued to be more vulnerable than terraced housing. However, it must be borne in mind that entry points are only vulnerable if they are accessible to offenders, and the extent to which this is the case will vary between property types.

- Homes vary in the extent to which offenders can move around freely in the grounds of a property without being detected, and offenders report that this amount of 'cover' has a strong influence on their decision to target a property (Bennett and Wright, 1983). Hence, properties will be at a particularly high risk of being burgled where natural surveillance is limited, and some types of housing may be particularly disadvantaged in this respect.

- Homes vary in the adequacy of security measures taken following a burglary. For instance, if no visible changes are made and offenders believe there are goods worth stealing inside, a 'good opportunity' is perceived, as they will already know how to gain access to the property and think it likely that they will be able to escape undetected. Hence, householders who do not upgrade their physical security measures adequately, particularly at the points of entry that the burglars used on a previous occasion, may be at a greater risk of revictimisation than other properties.

In summary, when considering which houses within a deprived area might be most at risk it is important to examine the influence of housing type in offenders' decision-making. For example, findings from the British Crime Survey demonstrate that while terraced housing and flats tend in general to be more at risk, detached housing appears to be more at risk when the influence of the 
area in which the housing is located is controlled (Budd, 1999). Here, we attempt to examine such trends in more detail and to use recorded crime data in investigating the interactions between housing, area type, and victimisation and repeat victimisation.

The specific questions that this paper sets out to answer are:

- Are certain types of housing more vulnerable to victimisation?

- Does the relative vulnerability of different types of housing vary by area type?

- Does the vulnerability of certain types of property to repeat victimisation vary by area type?

\section{Data}

Data relating to incidence of domestic burglary were obtained from Merseyside Police. Each burglary record contained the following fields:

- $\quad$ unique crime reference number;

- $\quad$ address of the offence;

- $\quad$ grid reference of the offence ( $\mathrm{x}$ and $\mathrm{y}$ coordinates);

- $\quad$ date of the offence;

- $\quad$ victim's name (stored as a phonetic code to protect anonymity);

- $\quad$ time of the offence;

- $\quad$ type of property victimised (eg terraced house);

- $\quad$ offender's modus operandi-point of entry; and

- $\quad$ offender's modus operandi-means of entry.

In order to process the data so that it was ready for analysis, the records were cleaned so that repeat victimisations could be identified on the basis of the address. The cleaned data set consisted of a total of 72,314 burglaries committed between 1st April 1995 and 1st April 2000 and, of these, 6338 were incidents of repeat victimisation (defined as burglary events that occurred at the same property within one year of each other). Expressed in a slightly different way, for the five-year period studied 8.77 per cent of the total number of burglaries were incidents of repeat victimization. Considering the rate of re-victimisation on a yearly basis (eg 1997-98 or 1998-99) rather than aggregated basis, the rate remained fairly stable over time, with a standard deviation of 0.44 per cent.

\section{Results}

\section{Influences of housing type and area}

To investigate how the risk of burglary and repeat burglary varies by housing type, the risks to different types of housing (semi-detached, detached, bungalows, terraced and flats) were derived and compared. Table 1 shows that, overall, terraced and semi-detached houses suffered the greatest number of incidents. To produce rates for each housing type, census information was used to identify the total numbers of properties of each type across Merseyside. ${ }^{3}$ When rates are considered it appears that the properties most at risk are flats and semi-detached houses, followed closely by 
terraced properties. Detached houses, in general, are at less risk. To examine the statistical significance of the pattern of results, the frequency with which each type of housing was victimised was compared with what would be expected on the basis of chance. The results confirmed that flats and semidetached properties were burgled more often than would be expected on the basis of chance.

Table I. Relative vulnerability of different housing types, April 1995-2000

\begin{tabular}{lccccc}
\hline & $\begin{array}{c}\text { Households } \\
\text { burgled }\end{array}$ & $\begin{array}{c}\text { Total number } \\
\text { of houses of type }\end{array}$ & $\begin{array}{c}\text { Prevalence } \\
\text { rate }\end{array}$ & $\begin{array}{c}\text { Total number } \\
\text { of incidents }\end{array}$ & $\begin{array}{c}\text { Incidence } \\
\text { rate }\end{array}$ \\
\hline Semi-detached & $24,915^{*}$ & 201,918 & 24.68 & 26,689 & 26.44 \\
Detached & $4122^{* *}$ & 53,364 & 15.45 & 4428 & 16.60 \\
Bungalows & 1895 & & & & \\
Terraced & $23,824^{* *}$ & 214,023 & 22.26 & 26,490 & 24.75 \\
Flats & $12,184^{*}$ & 103,199 & 23.61 & 13,515 & 26.19 \\
\hline
\end{tabular}

* indicates cell frequencies that were significantly higher than expected, using a chi-square test with one degree of freedom, $\mathrm{p}<0.05$.

** indicates cell frequencies that were significantly lower than expected, using a chi-square test with one degree of freedom, $\mathrm{p}<0.05$.

To illustrate the differences in the risk of suffering repeat victimisation for the various property types, a simple cross tabulation is displayed as Table 2 . A number of patterns are clearly evident. First, relative to the total number of incidents committed at each property type, terraced houses and flats were most likely (ten per cent) to be re-victimised. The risk of re-victimisation at other types of property was lower, with around six per cent of burgled properties being re-victimised. Second, most properties suffered only one revictimisation within each year studied; however, both terraced properties and flats were more likely to suffer greater numbers of revictimisations (up to four repeats). To see if the trends were statistically significant, the observed frequencies were compared with what would be expected on the basis of chance, assuming a poisson distribution. The results indicated that the number of repeats committed against semi-detached and detached properties were significantly below such expected levels. By contrast, repeats against terraced housing and flats occurred in significantly higher than expected numbers.

Table 2. Risk of revictimisation at different types of property

\begin{tabular}{lccccc}
\hline & \multicolumn{5}{c}{ Number of repeats } \\
& $\mathbf{0}$ & $\mathbf{1}$ & $\mathbf{2}$ & $\mathbf{3}$ & $\mathbf{4}$ \\
\hline Semi-detached* & 23,324 & 1431 & 142 & 13 & 5 \\
& $(93.6)$ & $(5.7)$ & $(0.6)$ & $(0.1)$ & $(0.0)$ \\
Detached* & 3896 & 231 & 19 & 2 & 1 \\
& $(93.9)$ & $(5.6)$ & $(0.5)$ & $(0.1)$ & $(0.1)$ \\
Bungalows & 1732 & 142 & 20 & 1 & \\
& $(91.4)$ & $(7.5)$ & $(1.1)$ & $(0.1)$ & - \\
Terraced** & 21,513 & 2020 & 236 & 46 & 9 \\
& $(90.3)$ & $(8.5)$ & $(1.0)$ & $(0.2)$ & $(0.0)$ \\
Flats** & 11,026 & 1012 & 122 & 21 & 3 \\
& $(90.3)$ & $(8.3)$ & $(1.0)$ & $(0.2)$ & $(0.0)$ \\
\hline
\end{tabular}

\footnotetext{
* indicates cell frequencies that were significantly lower than expected, assuming a poisson distribution, $\mathrm{p}<0.01$.

** indicates cell frequencies that were significantly higher than expected, assuming a poisson distribution, $\mathrm{p}<0.01$.
} 
Hence, it is apparent from Table 2 that in general some types of property, namely terraced properties and flats, are at a greater risk of re-victimisation than others. However, the analysis to this point has only considered the type of housing victimised and not the area in which properties are located. As discussed in the Introduction, it is evident from previous research that there is a clear area-effect on the risk of victimisation and re-victimisation. However, here we are particularly concerned with examining whether the area-effect influences the risk of victimisation uniformly for different types of property, or whether there is an interaction between these two types of risk factor. Hence, it is possible that the above results are actually an expression of the area in which the different types of property are located rather than because of a specific property-type risk per $s e$. For instance, on Merseyside there are over four times as many terraced houses as semi-detached houses in the most deprived areas of the county.

Consequently, further analyses were conducted that considered the effect of the area as well as that of housing type. Table 3 shows the risk of being burgled, expressed as a rate per 1000 households per year, for four different housing types in each of five different areas. These areas were defined by including the most affluent 20 per cent of areas in quintile 1 , the next most affluent 20 per cent in quintile 2 and so on, with the most deprived 20 per cent of areas being categorised as quintile 5 . The quintiles were produced by using the ward-level Index of Multiple Deprivation 2000. Using this approach, each of the 118 local authority wards in Merseyside were assigned to one of the five quintiles. Rates were produced using counts of each property type falling into each quintile for the whole of Merseyside. These totals are shown in Appendix 1.

Table 3. Prevalence rates for different types of housing in each quintile, April 1995-2000

\begin{tabular}{lcccc}
\hline & Semi & \multicolumn{2}{l}{ Housing type (raw numbers) } & \\
& Detached & Terraced & Flats \\
\hline Quintile 1 & 16.37 & 10.32 & 18.87 & 12.29 \\
& $(6176)$ & $(1793)$ & $(498)$ & $(318)$ \\
Quintile 2 & 20.39 & 17.85 & 18.44 & 15.87 \\
& $(6179)$ & $(1038)$ & $(2485)$ & $(1018)$ \\
Quintile 3 & 29.56 & 27.46 & 21.31 & 20.26 \\
& $(5206)$ & $(579)$ & $(6150)$ & $(1838)$ \\
Quintile 4 & 44.16 & 57.83 & 21.95 & 25.69 \\
& $(3965)$ & $(336)$ & $(7751)$ & $(2701)$ \\
Quintile 5 & 53.21 & 71.29 & 25.91 & 27.31 \\
& $(3377)$ & $(391)$ & $(6924)$ & $(6285)$ \\
\hline
\end{tabular}

Note: the prevalence rates in this table are expressed per 1000 households per annum, and use five years of burglary data (from April 1995 to April 2000).

It is clear from Table 3 that all types of property are more at risk from burglary in more deprived areas. However, what is particularly interesting is the fact that this pattern is far more pronounced in detached and semi-detached houses, to the extent that there is a clear interaction between these two risk factors, with such homes in deprived areas being disproportionately at risk. This pattern therefore suggests that, in the more deprived areas and for these properties in particular, some offenders seem to be employing specific targeting strategies, informed by the physical characteristics of a property, rather than committing purely opportunistic crimes. The pattern of results shown in Table 3 is also evident when a year-on-year analysis is done using the recorded crime data. This means that the findings shown in this table are consistent over time. 
Repeat victimisation and housing type

Whilst offenders' general targeting patterns may be influenced by housing type, it might be a different story where repeat burglaries are concerned, and hence further analyses were necessary. In order to examine repeats, we firstly undertook analysis to establish the relationship between deprivation and repeat victimisation within our data. The results, shown in Table 4, demonstrate that, as previous research suggests, there was indeed a higher risk of repeat victimisation for properties that were located in more deprived areas. In the most affluent quintile, only four per cent of the burglaries were incidents of repeat victimisation. By contrast, in the most deprived quintile ten per cent of the burglaries were repeats. Furthermore, properties located within the more deprived quintiles were more likely to see cases of multiple repeat victimisation than those within more affluent areas.

Table 4. Repeat victimisation and deprivation (one year's worth of data)

\begin{tabular}{lccccc}
\hline & \multicolumn{5}{c}{ Number of repeats (percentage of all incidents) } \\
& $\mathbf{0}$ & $\mathbf{1}$ & $\mathbf{2}$ & $\mathbf{3}$ & $\mathbf{4}$ \\
\hline Quintile 1 & 1505 & 60 & 4 & 1 & \\
& $(95.9)$ & $(3.8)$ & $(0.3)$ & $(0.1)$ & - \\
Quintile 2 & 1861 & 92 & 7 & & \\
& $(94.9)$ & $(4.7)$ & $(0.4)$ & - & - \\
Quintile 3 & 2359 & 160 & 15 & 3 & 1 \\
& $(92.9)$ & $(6.3)$ & $(0.6)$ & $(0.1)$ & $(0.0)$ \\
Quintile 4 & 2686 & 253 & 38 & 6 & 1 \\
& $(90.0)$ & $(8.5)$ & $(1.3)$ & $(0.2)$ & $(0.0)$ \\
Quintile 5 & 2979 & 357 & 45 & 4 & 2 \\
& $(88.0)$ & $(10.5)$ & $(1.3)$ & $(0.1)$ & $(0.1)$ \\
\hline
\end{tabular}

Table 5 considers the types of property repeatedly victimised, as well as their location. The 'totals' show that, overall, flats have the highest prevalence of repeat burglary. However, it is instructive to look at the results by type of area. As with the risk of burglary in general, the risk of re-victimisation increases as a function of the level of deprivation of an area. It is also clear that the risk of re-victimisation is not simply a function of housing type, or of deprivation in isolation, but rather of an interaction between them. This is particularly clear for detached housing, where the prevalence rate for the least deprived quintile is just over one-third of the equivalent rate for terraced housing, whilst the prevalence rate for detached housing in the most deprived quintile is almost three times the rate for terraced housing. Again, a year-on-year analysis demonstrates that the effect shown in Table 5 below is consistent over time.

Table 6 presents similar data in a different format for repeats occurring in the one-year period between April 1998 and April 1999. Here, the number of repeat households is given as a percentage of all the burgled houses of a particular type within a particular quintile. For instance, we see that 2.3 per cent of all the burgled semi-detached houses within quintile 1 were repeat victims of burglary within a one-year period. It is evident from this table that within the most affluent areas, burgled terraced houses are most at risk of a subsequent burglary. This could well be due to the fact that those living in such houses have fewer resources to invest in crime prevention measures than those living in other types of housing within these areas. In contrast, in the most deprived areas there is evidence that detached houses that have been burgled are more at risk of being revictimised-in fact, 15 per cent of such houses were re-victimised within one year. 
Crime Prevention and Community Safety: An International Journal 2005, 7 (1), 7-17

Table 5. Number of repeat households by housing type and quintile

\begin{tabular}{lcccc}
\hline & Semi & \multicolumn{2}{c}{ Housing type (prevalence rate) } & \\
& Detached & Terraced & Flats \\
\hline Quintile 1 & 266 & 82 & 33 & 11 \\
& $(0.71)$ & $(0.47)$ & $(1.25)$ & $(0.43)$ \\
Quintile 2 & 327 & 56 & 176 & 62 \\
& $(1.08)$ & $(0.96)$ & $(1.31)$ & $(0.97)$ \\
Quintile 3 & 349 & 36 & 521 & 146 \\
& $(1.98)$ & $(1.71)$ & $(1.81)$ & $(1.61)$ \\
Quintile 4 & 345 & 26 & 767 & 253 \\
& $(3.84)$ & $(3.13)$ & $(2.17)$ & $(2.41)$ \\
Quintile 5 & 304 & 52 & 815 & 687 \\
& $(4.79)$ & $(9.48)$ & $(3.05)$ & $(2.99)$ \\
Totals & $\mathbf{1 5 9 1}$ & $\mathbf{2 5 2}$ & $\mathbf{2 3 1 2}$ & $\mathbf{1 1 5 9}$ \\
& $(\mathbf{1 . 5 8})$ & $(\mathbf{0 . 9 4})$ & $(\mathbf{2 . 1 6})$ & $(\mathbf{2 . 2 4})$ \\
\hline
\end{tabular}

Table 6. Distribution of repeat burglaries within burgled houses (one year's worth of data, percentage of repeats of all burgled properties of that type and that quintile, in parentheses)

\begin{tabular}{|c|c|c|c|c|c|}
\hline & \multicolumn{5}{|c|}{$\begin{array}{c}\text { Housing type } \\
\text { (percentage repeats of all burgled properties) }\end{array}$} \\
\hline & Semi & Detached & Bungalows & Terraced & Flats \\
\hline Quintile 1 & $\begin{array}{c}22 \\
(2.3)\end{array}$ & $\begin{array}{l}13 \\
(3.6)\end{array}$ & $\begin{array}{c}5 \\
(3.9)\end{array}$ & $\begin{array}{c}6 \\
(9.2)\end{array}$ & $\begin{array}{c}1 \\
(1.6)\end{array}$ \\
\hline Quintile 2 & $\begin{array}{c}36 \\
(3.9)\end{array}$ & $\begin{array}{c}8 \\
(3.5)\end{array}$ & $\begin{array}{c}5 \\
(4.7)\end{array}$ & $\begin{array}{c}33 \\
(7.4)\end{array}$ & $\begin{array}{c}7 \\
(4.3)\end{array}$ \\
\hline Quintile 3 & $\begin{array}{l}45 \\
(5.6)\end{array}$ & $\begin{array}{c}3 \\
(2.8)\end{array}$ & $\begin{array}{c}6 \\
(7.4)\end{array}$ & $\begin{array}{l}116 \\
(9.6)\end{array}$ & $\begin{array}{c}26 \\
(7.2)\end{array}$ \\
\hline Quintile 4 & $\begin{array}{c}60 \\
(9.4)\end{array}$ & $\begin{array}{c}8 \\
(9.4)\end{array}$ & $\begin{array}{c}4 \\
(5.6)\end{array}$ & $\begin{array}{l}149 \\
(9.8)\end{array}$ & $\begin{array}{c}44 \\
(9.0)\end{array}$ \\
\hline Quintile 5 & $\begin{array}{c}43 \\
(7.0)\end{array}$ & $\begin{array}{c}12 \\
(15.0)\end{array}$ & $\begin{array}{c}8 \\
(12.3)\end{array}$ & $\begin{array}{c}155 \\
(11.5)\end{array}$ & $\begin{array}{c}142 \\
(11.5)\end{array}$ \\
\hline
\end{tabular}

Analysis of point of entry

A final piece of analysis addressed the question raised in the introduction concerning the number of entry points used to burgle different types of property. It was hypothesised that one of the reasons that detached properties might be more vulnerable is because they offer a larger number of points of entry. Table 7 shows a cross-tabulation of the entry points used by type of property, produced using the data available concerned with the offender's modus operandi in each incident. However, since there were a possible 19 entry points recorded and since many of these were only used very rarely, data for some of the entry points were combined to give the columns shown in Table 7. The table has five columns, which include the three most frequently used access points and two other columns which represent an aggregation of the values for a number of other access points. With the exception of flats, it is clear that the entry point most frequently used by offenders is the ground-floor rear window. 
Crime Prevention and Community Safety: An International Journal 2005, 7 (1), 7-17

Table 7. Point of entry used to gain access to properties for all incidents of burglary

\begin{tabular}{lccccc}
\hline & \multicolumn{5}{c}{ Point of entry (percentage) } \\
& $\begin{array}{c}\text { Front } \\
\text { door }\end{array}$ & $\begin{array}{c}\text { Rear } \\
\text { door }\end{array}$ & $\begin{array}{c}\text { Ground floor } \\
\text { rear window }\end{array}$ & $\begin{array}{c}\text { Other } \\
\text { windows* }\end{array}$ & $\begin{array}{c}\text { Other } \\
\text { entry points** }\end{array}$ \\
\hline Terraced (7) & 4765 & 5801 & 8738 & 2786 & 833 \\
& $(20.79)$ & $(25.31)$ & $(38.12)$ & $(12.15)$ & $(3.64)$ \\
Flats (7) & 2398 & 296 & 670 & 687 & 235 \\
& $(55.9)$ & $(6.9)$ & $(15.6)$ & $(16.0)$ & $(5.5)$ \\
Semi-Detached (8) & 4242 & 4880 & 8359 & 3373 & 2468 \\
& $(18.19)$ & $(20.92)$ & $(35.84)$ & $(14.46)$ & $(10.58)$ \\
Detached (10) & 704 & 749 & 1207 & 759 & 585 \\
& $(17.58)$ & $(18.71)$ & $(30.15)$ & $(18.96)$ & $(14.61)$ \\
Bungalows (7) & 419 & 306 & 753 & 264 & 147 \\
& $(22.18)$ & $(16.20)$ & $(39.86)$ & $(13.98)$ & $(7.78)$ \\
All properties & 12,528 & 12,032 & 19,727 & 7869 & 4268 \\
& $(22.20)$ & $(21.32)$ & $(34.96)$ & $(13.95)$ & $(7.56)$ \\
\hline
\end{tabular}

Note: figures in parentheses in the left-hand column refer to the total number of entry points used at each type of property through which entry was gained for at least one per cent of the burglaries.

* Front window (ground floor), rear window (upper floor) and side window.

** All other entry points, including patio doors, side window (upper floor) and skylights.

What is of particular interest in Table 7 is that, across all burglaries, offenders used a number of different entry points, and that the number of entry points used (figures in brackets in the first column of Table 7) varied by type of property. Specifically, relative to flats and terraced properties, for detached and semi-detached houses offenders tended to exploit a greater number of access points, and also frequently used 'other' entry points such as side windows, patio doors and skylights (34 per cent and 25 per cent of crimes respectively — see Table 7). In contrast, but not surprisingly, entry to flats was gained most frequently (56 per cent) via the front door, which is generally the most accessible entry point. The information shown in Table 7 therefore suggests that burglars do tend to exploit more points of entry in detached and semi-detached housing. This could be a particular problem in areas where the burglary rate is particularly high, as giving a greater number of opportunities for access will leave such properties more exposed.

\section{Discussion}

This paper has investigated the relationship between area type, housing type and levels of victimisation and repeat victimisation. The results have demonstrated that, first, terraced houses suffer from a greater number of burglaries than other housing types. However, relative risks are often masked by using general denominators such as the total number of households. When housing-specific denominators are used, it is flats and semi-detached houses that are at the greatest risk, followed by terraced housing, and finally detached houses. Secondly, far greater insights can be gained by considering also the type of area in which properties are situated. The results of this analysis strongly suggest that while generally at less of a risk, detached housing is considerably more or less vulnerable depending on the type of area in which it is located. Specifically, detached housing in more deprived areas is at over seven times the risk of being burgled than such housing in the most affluent areas. Furthermore, detached housing in poorer areas is at almost three times the risk of being burgled as terraced housing in these areas. The most intuitive explanation for this heightened risk is that detached houses in poor areas are an indication of possible affluence, and therefore a higher burglary yield. 
It is instructive to examine the hierarchy of risk when both housing type and area type are taken into account. Appendix $2^{4}$ shows the area and housing type combinations rank-ordered in terms of their level of risk of burglary. We see that detached houses in the most deprived areas suffer from the highest risk, whereas detached houses in the most affluent areas are at the lowest risk. Interestingly, the six most high-risk combinations all involve detached or semi-detached housing in relatively deprived areas. We also see that terraced housing in relatively affluent areas suffers higher risks of burglary than all the other housing types.

These findings have particular relevance to crime prevention in practice. They suggest that the general mentality that whatever is 'deprived' should receive treatment over and above whatever is 'affluent' might be misinformed. It is true that the burglary rate in more deprived areas is higher than elsewhere, and it is also true that there are likely to be more terraced houses in such areas. However, it does not follow that the terraced housing should always be first on the list for assistance. In fact, it might be more effective to target the detached properties first, because the results show that they are more at risk and that they have the considerable advantage that there are likely to be less of them overall, which makes the task of target-hardening them easier.

Further analysis concerned repeat victimisation. Here we see, perhaps as expected, that in general terraced properties and flats were more vulnerable to repeat victimisation than semi-detached and detached properties. We also observe that housing located in more deprived areas routinely suffered from higher levels of repeat victimisation. However, there was also evident selectivity in the types of housing that suffered repeats across different types of area. The risk of a detached house suffering repeat victimisation is over 20 times greater in the most deprived than in the most affluent areas. Furthermore, it is true of repeat victimisation, as well as victimisation per se, that detached properties in deprived areas are over three times as likely to suffer as terraced houses. In a one-year period, 15 per cent (almost one in seven) of burgled detached properties in such areas suffered from at least one repeat incident. It is clear from these results that even crime prevention based on repeat victimisation strategies undertaken in more deprived areas should ensure that detached houses are sufficiently protected.

The higher risk of victimisation and re-victimisation associated with detached houses in deprived areas may, of course, be due to a combination of factors. For example, these houses might have relatively restricted natural surveillance or a greater number of access points. Indeed, the results from the analysis of the point of entry favoured by offenders demonstrated that one of the potential reasons for the vulnerability of detached houses is that burglars have a range of different entry points to choose from. This suggests that any assistance given to these properties should consider the strength of all entry points. Furthermore, given the behavioural consistency with which offenders are believed to commit offences (Adderley and Musgrove, 2003), it might be particularly advisable with previously burgled properties to ensure that the point of entry used in the past was secured, to help discourage repeat victimisation.

Of course, many factors other than those considered here may inform an offender's decision as to which households to target. These include, for instance, the degree to which a house is well maintained and whether the housing is privately owned or part of a housing association. For instance, a well-looked-after house might contain a larger number of crime reduction features than neighbouring houses. This could protect it against burglary, and perhaps distraction burglary in particular, as poorly maintained houses may signal possible occupancy of the old or infirm. Modern housing association properties have fairly high standards of security compared to their private counterparts, which could in turn make them less of a target. Nevertheless, it is apparent from the results presented above that housing type does have a significant part to play in offender decision-making, and should consequently inform crime prevention practice. 
The most important lesson of the research reported here is that crime reduction and community safety partners must not commit the ecological fallacy of assuming that crime risk works the same way at both areal and individual levels. Indeed, we have demonstrated that houses that are more ostentatiously affluent and located in deprived areas are more at risk of burglary than their more modest-looking counterparts. Practitioners should examine individual level risks before making the assumption that the target-hardening of households that could be indicating relative deprivation will be treating the most serious crime problems, especially within the context of deprived areas.

Perhaps, instead of turning to the correlation-based literature that relates crime to deprivation, practitioners should draw upon the work of Cornish and Clarke (1986). Their rational choice theory stipulates that within an opportunistic framework offenders will seek to maximise rewards. When faced with two targets where all other factors are the same, it would seem intuitively that an offender will select a target which displays stereotypical signs of relative affluence.

Appendix I. Number of properties of different types within area quintiles

\begin{tabular}{lcccc}
\hline & Semi & $\begin{array}{c}\text { Denominators: type of property } \\
\text { Detached }\end{array}$ & Terraced & Flats \\
\hline Quintile 1 & 75,436 & 34,759 & 5279 & 5172 \\
Quintile 2 & 60,608 & 11,629 & 26,958 & 12,830 \\
Quintile 3 & 35,222 & 4217 & 57,709 & 18,147 \\
Quintile 4 & 17,958 & 1662 & 70,628 & 21,026 \\
Quintile 5 & 12,694 & 1097 & 53,449 & 46,024 \\
Totals & 201,918 & 53,364 & 214,023 & 103,199 \\
\hline
\end{tabular}

Appendix 2. Hierarchy of risk

\begin{tabular}{lcc}
\hline Housing type & Area quintile & Rank \\
\hline Detached & 5 & 1 \\
Detached & 4 & 2 \\
Semi-detached & 5 & 3 \\
Semi-detached & 4 & 4 \\
Semi-detached & 3 & 5 \\
Detached & 3 & 6 \\
Flats & 5 & 7 \\
Terraced & 5 & 8 \\
Flats & 4 & 9 \\
Terraced & 4 & 10 \\
Terraced & 3 & 11 \\
Semi-detached & 2 & 12 \\
Flats & 3 & 13 \\
Terraced & 1 & 14 \\
Terraced & 2 & 15 \\
Detached & 2 & 16 \\
Semi-detached & 1 & 17 \\
Flats & 2 & 18 \\
Flats & 1 & 19 \\
Detached & 1 & 20 \\
\hline
\end{tabular}

Notes: Quintile 5 comprises the most deprived areas and Quintile 1 the most affluent.

$1=$ the highest-ranked risk, 20 the lowest-ranked. 


\section{Notes}

Kate Bowers and Shane Johnson are Senior Lecturers, and Ken Pease is Visiting Professor, in the Jill Dando Institute of Crime Science, University College London; email: k.bowers@ucl.ac.uk.

See at http://www.calderdale.gov.uk/community/safety/audit/victim.html. Accessed 27th January 2004.

Note that the census does not provide unique counts of the number of bungalows, and hence it was not possible to produce prevalence rates for this category.

The authors would like to thank one of the reviewers for suggesting this Appendix.

\section{References}

Adderley, R. and Musgrove, P. (2003) MO Modelling of Group Offending: A Data Mining Case Study. International Journal of Police Science and Management. Vol. 5, No. 4, pp 267-76.

Baldwin, J. and Bottoms, A.E. (1976) The Urban Criminal. London: Tavistock.

Bennett, T. and Wright, R. (1983) Constraints to Burglary: The Offender's Perspective. In Clarke, R. and Hope, T. (eds) Coping with Burglary. Boston, MA: Kluwer-Nijhoff.

Block, R. (1979) Community, Environment and Violent Crime. Criminology. Vol. 17, No. 17, pp 46-57.

Budd, T. (1999) Burglary of Domestic Dwellings: Findings from the British Crime Survey. Home Office Statistical Bulletin No. 4/99. London: Home Office Research and Statistics Directorate.

Bursik, R.J. (1988) Social Disorganisation and Theories of Crime and Delinquency: Problems and Prospects. Criminology. Vol. 26, No. 5, pp 519-51.

Curry, G.D. and Spurgel, I. (1988) Gang Homicide, Delinquency and Community. Criminology. Vol. 26, No. 3, pp 381-406.

Cornish, D. and Clarke, R.V. (1986) The Reasoning Criminal. New York: Springer-Verlag.

Durkheim, E. (1897) Le Suicide. Paris: F. Alcan.

Ellingworth, D., Tseloni, A. and Pease, K. (1997) Prior Victimisation and Crime Risk. International Journal of Risk, Security and Crime Prevention. Vol. 2, No. 3, pp 201-14.

Herbert, D.T. (1977) An Areal and Ecological Analysis of Delinquency Residence: Cardiff 1966 and 1971. Tijdschrift voor Economische en Sociale Geographie. Vol. 68, No. 1. pp 83-9.

Hirschfield, A.F.G., Bowers, K.J. and Brown, P.J.B. (1995) Exploring Relations Between Crime and Disadvantage on Merseyside. European Journal on Criminal Policy and Research. Vol. 3, No. 3, pp 93-112.

Johnson, S.D., Bowers, K.J. and Hirschfield, A.F.G. (1997) New Insights into the Spatial and Temporal Distribution of Repeat Victimisation. British Journal of Criminology. Vol. 37, No. 2, pp 224-41.

Kershaw, C., Budd, T., Kinshott, G., Mattinson, J., Mayhew, P. and Myhill, A. (2000) The 2000 British Crime Survey: England and Wales. Home Office Statistical Bulletin No. 18/00. London: Home Office.

Maguire, M. (1982) Burglary in a Dwelling: The Offence, the Offender and the Victim. London: Heinemann.

Osborn, D.R. and Tseloni, A. (1998) The Distribution of Household Property Crimes. Journal of Quantitative Criminology. Vol. 14, No. 3, pp 307-30.

Sampson, R.J. and Raudenbush, S.W. (1999) Systematic Social Observation of Public Spaces: A New Look at Disorder in Urban Neighbourhoods. American Journal of Sociology. Vol. 105, No. 3, pp 603-51.

Trickett, A., Osborn, D.R. and Ellingworth, D. (1995) Property Crime Victimisation: The Roles of Individual and Area Influence. International Review of Victimology. Vol. 3, No. 4, pp 273-95.

Tseloni, A., Osborn, D.R., Trickett, A. and Pease, K. (2002) Modelling Property Crime Using the British Crime Survey: What Have we Learnt? British Journal of Criminology. Vol. 42, No. 1, pp 109-28.

Winchester, S. and Jackson, H. (1982) Residential Burglary: The Limits of Prevention. Home Office Research Study No. 74. London: Stationery Office. 